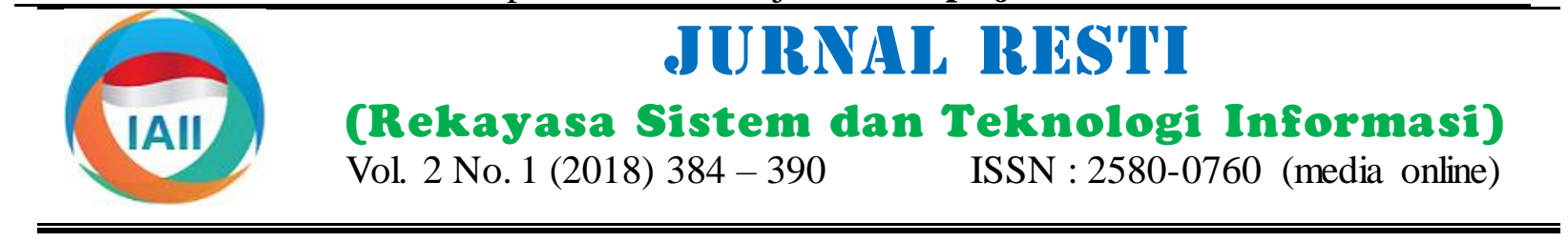

\title{
Sistem Informasi Geografis Daerah Yang Layak Menerima Daging Qurban Di Wilayah Kota Padang
}

\author{
Sotar $^{\mathrm{a}}$, Dani Mardianto ${ }^{\mathrm{b}}$ \\ ${ }^{a}$ Sistem Informasi, STMIK Indonesia Padang, Jln. Khatib Sulaiman Dalam No.1 Padang email: sotar@stmikindonesia.ac.id \\ ${ }^{\mathrm{b}}$ Sistem Informasi, ST MIK Indonesia Padang, Jln. Khatib Sulaiman Dalam No.1 Padang email: Namagua7@gmail.com
}

\begin{abstract}
Qurban is one of the worship that is held every year in the month dzulhijjah, the goal is closer to the creator. One of the functions of Qurban worship is as a form of concern to the dhuafa \&\#39; or the needy means that people who can slauchetering qurban animals can share the people who can not afford. In the city of Padang there are still many suburbs worthy of receiving Qurban meat, while in urban areas there are many sacrifices of Qurban animals and many excess meat quotas, but they only distribute them in urban areas with relatively good economy and certain orphanages, this results in the meat of Qurban accumulate in certain locations only. One of the causes of the Committee is difficult to get clear information about the location or area that really deserves the meat Qurban. The geographic information system built can provide solutions and information to the Qurban Committee or Mosque Board and other institution of Qurban meat distributor to the lack of information about the area, place, trip route, distance, number of people, the number of Qurban animals in each mosque in Padang city as well as areas categorized as worthy to receive the meat of Qurban. Thus the distribution of Qurban meat distributed evenly, the right target and the function of the Qurban worship achieved.
\end{abstract}

Keywords: Information System, Geographic, Qurban

\begin{abstract}
Abstrak
Qurban merupakan salah satu ibadah y ang dilaksanakan setiap tahun di bulan Dzulhijjah, tujuannya mendekatkan diri kepada sang khaliq. Salah satu fungsi dari ibadah Qurban adalah sebagai bentuk kepedulian kepada kaum dhuafa' atau fakir miskin artinya bahwa orang y ang mampu berqurban dapat berbagi pada orang yang tidak mampu. Di Kota Padang masih banyak daerah pinggiran y ang lay ak menerima daging Qurban, sementara di daerah perkotaan banyak sembelihan hewan Qurban dan banyak kuota daging y ang berlebih, akan tetapi mereka hanya mendistribusikannya di daerah perkotaan yang ekonominya relatif bagus dan Panti asuhan tertentu, hal ini mengakibatkan daging Qurban menumpuk di lokasi tertentu saja. Salah satu peny ebabny a Panitia kesulitan mendapatkan informasi y ang jelas tentang lokasi atau daerah yang benar-benar lay ak menerima daging Qurban. Sistem informasi geografis y ang dibangun dapat memberikan solusi dan informasi pada Panitia Qurban atau Pengurus Masjid dan lembaga Penyalur daging Qurban lainnya terhadap kurangnya informasi tentang daerah, tempat, rute perjalan, jarak tempuh, jumlah warga, jumlah hewan Qurban di masing-masing Masjid di kota Padang serta daerah yang terkategori lay ak menerima daging Qurban. Dengan demikian pendistribusian daging Qurban tersalurkan secara merata, tepat sasaran serta fungsi dari ibadah Qurban tercapai.
\end{abstract}

Kata Kunci: Sistem Informasi, Geografis, Qurban

(C) 2018 Jurnal RESTI

\section{Pendahuluan}

Perkembangan teknologi sekarang ini khususnya teknologi informasi berkembang dengan sangat pesat, Sistem informasi geografis adalah suatu sistem yang yang memungkinkan setiap manusia selalu berbasiskan komputer dan digunakan dalam menginginkan kemudahan, kecepatan dan sistem menyimpan serta memanipulasi informasi geografis . informasi yang relevan untuk memudahkan aktifitas. Sistem informasi geografis dibangun dalam Sistem Informasi Geografis (SIG) sebagai suatu mengumpulkan, menyimpan serta menganalisis obyekperangkat yang digunakan dalam pemetaan dan analisa obyek dan fenomena-fenomena, pada lokasi geografis terhadap banyak aktifitas di atas permukaan bumi yang merupakan karakteristik yang penting atau kritis menjadi salah satu jawaban untuk mengatasi keinginan untuk dianalisis.[1] ini. Penggunaan sistem informasi geografis salah satunya dapat mempermudah Pengurus Masjid maupun
Panitia Qurban dalam melakukan distribusi daging Qurban di wilayah Kota Padang.

Diterima Redaksi : 24-01-2018 $\mid$ Selesai Revisi : 17-04-2018 $\mid$ Diterbitkan Online : 18-04-2018 
penyembelihan hewan. Sementara ritual Qurban adalah adalah sistem yang menekankan pada unsur informasi salah satu pelaksapnaan ibadah orang muslimin, untuk geografis.[4]

rangka menjalankan perintah Allah SWT. menjalankan ibadah Qurban itu dilaksanakan pada bulan Dzulhijjah, dalam penanggalan Is lam yaitu pada tanggal 10 yang Beberapa kemampuan dari SIG disebut hari nahar dan tanggal 11,12 dan 13 yang disebut hari tasyrik bertepatan pada Hari Raya Idul Adha. Seorang mukmin yang benar, selalu menginginkan keridhaan serta kasih sayang Allah SWT selama hidupnya.[2]

Dalam hal permasalahan Qurban berdasarkan observasi yang dilakukan, belum ada yang menyediakan sistem informasi geografis mengenai daerah mana saja yang belum tersentuh dalam pendistribusian daging Qurban di wilayah Kota Padang, sehingga Pengurus Masjid atau Panitia Qurban kesulitan dalam mencari lokasi yang layak menerima daging Qurban di wilayah Kota Padang. Daging Qurban hanya didistribusikan di lingkungan Masjid saja yang terkadang daerah tersebut sudah mendapatkan daging Qurban dari Masjid lain, yang menyebabkan penyebaran daging Qurban di wilayah Kota Padang kurang merata. Penggunaan aplikasi GIS ini akan mempermudah Pengurus Masjid atau Panitia Qurban dalam mengetahui data penyembelihan hewan Qurban di wilayah Kota Padang.

Sistem informasi geografis lokasi daerah yang layak menerima daging Qurban di wilayah Kota Padang yang akan dibangun dengan menggunakan WebGIS, Google Maps, Google Maps API dapat diakses secara online dengan menggunakan internet atau web berdasarkan panduan dari pemetaan google atau yang lebih dikenal sebagai google maps. Pembuatan aplikasi ini diharapkan dapat mempermudah Pengurus Masjid atau Panitia Qurban untuk mengetahui daerah-daerah mana saja 2.3 Qurban yang yang layak mendapatkan daging Qurban, sehingga mempermudah mendistribusikan daging Qurban di wilayah Kota Padang.

\section{Memetakan letak}

Kemampuan ini dapat memungkinkan seseorang dalam mencari dimana letak suatu daerah, benda ataupun yang lainnya dipermukaan bumi ini. Adapaun fungsi ini bisa dimanfaatkan seperti dalam mencari tempat-tempat yang penting dan lainnya yang ada pada peta.

2. Memetakan kuantitas

Adapun dengan melihat penyebaran kuantitas yang dapat mencari tempat-tempat yang sesuai kriteria yang diinginkan dan dimanfaatkan pada pengambilan keputusan atau untuk mencari hubungan pada masing-masing tempat.

3. Memetakan kerapatan

Dalam hal memetakan kerapatan bisa membagi dengan mudah konsentrasi daerah yang lebih mudah untuk dipahami dengan seragam ke dalam unit-unit, contohnya dengan berbeda-beda warna diberikan kepada daerah-daerah yang mempunyai konsentrasi yang tertentu. Sementara pemetaan kerapatan ini yang biasanya dimanfaatkan pada data-data yang jumlahnya besar seperti halnya sensus penduduk.

4. Memetakan apa saja yang ada pada luar dan di dalam suatu area tersebut.

Sig dimanfaatkan dalam memonitor apa yang terjadi serta keputusan apa yang ada pada luar area.[5]

\section{Tinjauan Pustaka}

\subsection{Sistem Informasi Geografis}

Sistem Informasi Geografis (SIG) adalah sistem informasi yang dapat digunakan dalam memasukkan, menyimpan, memangggil kembali, mengolah, Adapun pengertian Qurban menurut terminologi syarae menganalis is serta menghasilkan data yang bereferensi tidaklah ada perbedaan bahwa Qurban adalah hewan geografis (data geospatial), dalam mendukung yang khusus disembelih pada waktu hari raya Qurban pengambilan keputusan untuk perencanaan serta yang diistilahkan dengan Idul al-Adha pada tanggal 10 pengelolaan penggunaan lahan, sumber daya alam, Dzul Hijjah dan pada hari-hari raya Tasyriq yaitu lingkungan transportasi, fasilitas kota, dan pelayanan tanggal 11,12, dan 13 Dzul Hijjah.

umum lainnya.[3]

Hari raya Idul Adha yang pada umumnya lebih dikenal Sistem informasi geografis (SIG) adalah gabungan 3 dengan hari raya Qurban, tentunya tidak hanya sekadar unsur pokok; sistem, informasi, serta geografis. Dengan penyembelihan, pembagian dan penyebaran daging demikian, pengertian pada ke-tiga unsur pokok ini Qurban saja, namun ada makna yang mengiringinya. sangat membantu untuk memahami SIG. Dengan Ibadah Qurban itu ada manfaat yang memiliki nilai guna melihat unsur-unsur pokoknya, maka jelas bahwa SIG apabila ditafakuri dengan hati yang jernih. Ibadah juga adalah tipe sistem informasi, akan tetapi dengan Qurban yang kita laksanakan sudah saatnya berfungsi adanya tambahan unsur geografis. Oleh karena itu, SIG bukan hanya sekedar menggugurkan kewajiban namun 
lebih dari daripada itu dapat memberikan manfaat sekaligus sebagai solusi dan jawaban atas suatu kondisi riil yang terjadi di dalam masyarakat.[7]

\subsection{Pendistribusian Daging Qurban}

Untuk mengatasi masalah pendistribusian daging Qurban di kota Padang yang ada pada saat ini, diperoleh perancangan untuk membangun suatu sistem yang baru agar kebutuhan pada sistem ini terpenuhi. Analisis kebutuhan sistem secara garis besar membahas tentang kebutuhan sistem aplikasi. Setelah itu Pengguna dapat menggunakan aplikasi GIS lokasi daerah yang layak menerima daging Qurban melalui Computer atau Handphone yang terhubung ke internet yang bertujuan untuk mengetahui informasi tentang lokasi-lokasi yang telah mendapatkan distribusi daging Qurban dari Masjid-Masjid di wilayah Kota Padang.

Sistem yang dibangun ini mampu mengatasi permasalahan yang ada pada sistem lama, sehingga kebutuhan sistem yang lama dapat terpenuhi. Sistem informasi geografis lokasi yang layak menerima daging Qurban di wilayah Kota Padang ini memiliki beberapa elemen yang mendukung integrasi sistem. Elemenelemen sistem informasi geografis lokasi daerah yang layak menerima daging Qurban tersebut.

Berikutnya kajian kepustakaan pada intinya dilakukan untuk mendapatkan gambaran tentang hubungan topik penelitian yang akan diajukan dengan penelitian sejenis yang pernah dilakukan oleh para peneliti sebelumnya, sehingga tidak terjadi pengulangan yang tidak perlu dan mubazir. Oleh karenanya sebelum menulis penelitian ini telah dilakukan penelusuran terhadap penelitianpenelitian sebelumnya apakah ada yang berhubungan dengan penelitian yang diteliti.

Dari hasil penelusuran tersebut, tidak ditemukan adanya penelitian sebelumnya yang membahas secara khusus
SIG tentang pendistribusian daging Qurban. Selain itu, hanya ditemukan sebatas yang berkaitan dengan sistem informasi geografis, akan tetapi yang berkaitan khusus dengan sistem informasi geografis daerah yang layak menerima daging Qurban di kota Padang belum ada yang membahas. Berikut hasil penelusuran yang dilakukan terhadap beberapa penelitian yang ada hubungannya dengan masalah sistem informasi geografis di antaranya:

1. Rancang bangun SIG sebaran yang berkaitan dengan tempat riset teknologi informasi yang penelitiaannya di Kota Garut. Sebagai penulisnya adalah Yosep Bustomi, M. Ali Ramdhani, dan Rinda Cahyana.[8]

2. Membahas SIG lokasi perguruan tinggi yang penelitiannya di daerah istimewa yogyakarta yang Motumona, Uning Lestari, dan Erfanti memudahkan dalam perancangan SIG. Sesudah data Fatkhiyah.[9]
3. Penelitian yang ditulis Dony Novaliendry dengan topik aplikasi game geografi berbasis multimedia interaktif untuk siswa kelas ix di SMPN 1 Rao.[10]

4. Pemanfaatan SIG open source untuk pelayanan kesehatan masyarakat lokasi penelitiannya di Yogyakarta. Yang diteliti oleh Budi Santosa.[11]

Sementara penelitian yang dibuat berbeda dengan yang di atas bahkan belum ada yang membahas tentang sistem informasi geografis lokasi daerah yang layak menerima daging Qurban di wilayah Kota Padang

Berdasarkan referensi di atas, dapat dilihat bahwa kajian yang akan ditelaah dalam penelitian ini belum diungkapkan yang berkaitan dengan topik pembahasan ini. Oleh karena itu, penting sekali untuk membuat sistem informasi geografis daerah yang layak menerima daging Qurban.

\section{Metodologi Penelitian}

Adapun metodologi penelitian yang di buat adalah serangkaian kegiatan yang mendukung pada proses penelitian ini, serta aktifitas lainnya juga sangat mendukung proses penelitian yang dituju. Adapun tahapan yang mesti dilaksanakan pada penelitian ini adalah :

\subsection{Tahap Persiapan}

Dalam tahap ini merupakan yang paling pertama dilakukan sebelum melakukan proses sebuah penelitian. Oleh karena itu tahapan ini, sangat penting pada pengorganisasian pengumpulan data lapangan serta data atribut. Sedangkan tujuan tahapan ini mempersiapkan rencana kerja yang akan digunakan dalam melakukan suatu proses penelitian diawali dengan studi literatur dalam berbagai sumber yang ada sampai pada perancangan SIG dan aplikasi programnya.

\subsection{Dalam Tahapan Mengumpulkan Data}

Pada tahapan ini dilakukan pengumpulan data spasial serta data atribut. Maksud data spasial ialah data peta yang akan dijadikan dasar dalam membuat konsep perancangan SIG. Sedangkan data atribut adalah data pelengkap yang dipakai untuk informasi data spasial. Data atribut menyajikan informasi mengenai data-data daerah yang layak menerima daging Qurban di Kota Padang

\subsection{Tahap Pengolahan Data}

Dalam tahap ini merupakan tahapan yang dilaksanakan setelah didapatkan data yang sudah terkumpul. Apabila data-data yang dimaksud sudah lengkap, maka selanjutnya menggabungkan data spasial tersebut dengan data atibutnya. Namun sebelum melaksanakan spasial dan data atribut tersebut digabungkan, maka tahap selanjutnya membangun SIG dengan memakai 
software arc wiew. Dari hasil SIG itu, dalam proses yang lebih lanjut ialah melaksanakan analisa SIG.

\section{Tahap Akhir}

Pada tahap ini merupakan tahap yang dibuat dengan mendokumentasikan secara tertulis pada hasil penelitian yang sudah dilaksanaka dari pertama sampai dengan selesainya penelitian laporan akhir. Adapun diagram alir penelitian terlihat pada Gambar 1.

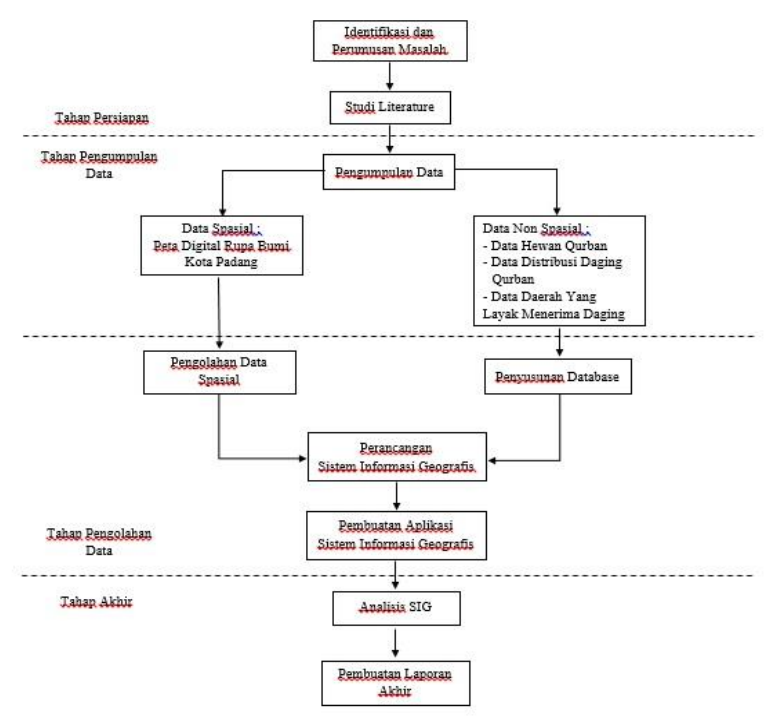

Gambar 1. Diagram Alir Metode Penelitian

\section{Hasil dan Pembahasan}

\subsection{Analis dan Desain}

Untuk mengatasi masalah yang ada pada saat ini, diperoleh perancangan untuk membangun suatu sistem yang baru agar kebutuhan pada sistem ini terpenuhi. Analis is kebutuhan sistem secara garis besar membahas tentang kebutuhan sistem aplikasi. Setelah itu Pengguna dapat menggunakan aplikasi GIS lokasi daerah yang layak menerima daging Qurban melalui Computer yang terhubung ke internet yang bertujuan untukmengetahui informasi tentang lokasi-lokasi yang telah mendapatkan distribusi daging Qurban dari Masjid-masjid di wilayah Kota Padang.

Sistem baru ini mengatasi permasalahan yang ada pada sistem lama, sehingga kebutuhan sistem yang lama dapat terpenuhi. Sistem informasi geografis lokasi yang layak menerima daging Qurban di wilayah Kota Padang ini memiliki beberapa elemen yang mendukung integrasi sistem. Elemen-elemen sistem informasi geografis lokasi daerah yang layak menerima daging Qurban tersebut, adapun Use Case diagram sistem informasi lokasi yang layak menerima seperti pada Gambar 2.

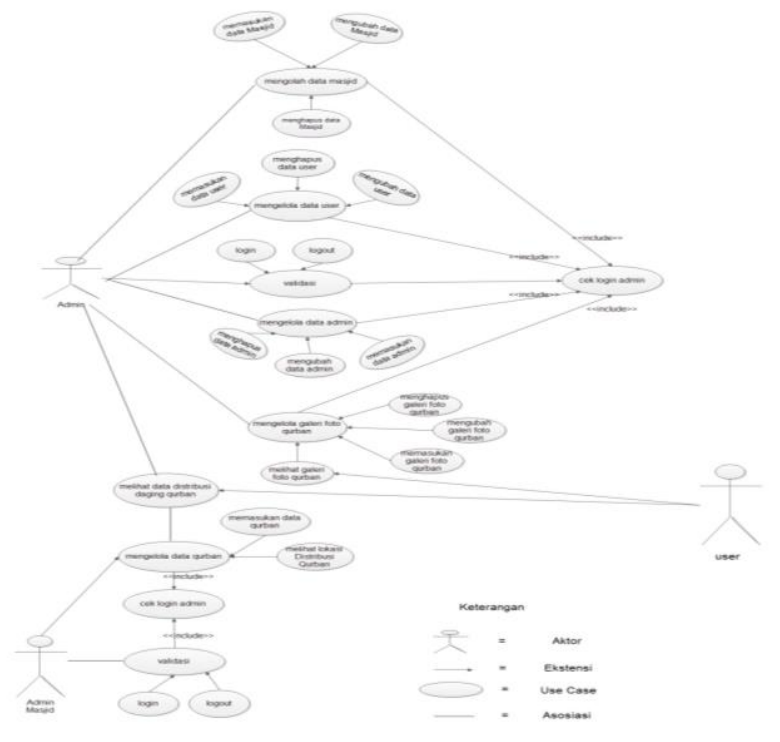

Gambar.2 Use Case Diagram Sistem Informasi Geografis Lokasi Yang Layak Menerima Daging Qurban Di Wilayah Kota Padang

Analisis sistem adalah penguraian dari suatu informasi yang utuh ke dalam bagian-bagian komponennya untuk mengidentifikasi permasalahan-permasalahan yang terjadi, sehingga dapat diusulkan perbaikannya. Tahap analisis merupakan prosedur yang penting, karena kesalahan atau kelemahan sistem pada tahap sebelumnya akan menyebabkan kesalahan ditahap selanjutnya. Adanya perencanaan suatu sistem yang baru diharapkan akan dapat mengfungsikan sistem yang lebih baik dari sistem sebelumnya.

Adapun analisis sistem yang sedang berjalan saat ini mempelajari pengolahan data distribusi daging Qurban yang berada di Masjid maupun Mushala yang berada di Kota Padang dan memetakan daerah mana saja yang layak menerima daging Qurban, kemudian dianalisis untuk mengetahui perincian sistem yang lebih detail. Setelah dilakukan penelitian, diperoleh gambaran singkat tentang keadaan sistem dan beberapa kelemahan yang ada. Ada beberapa kelemahan pada sistem yang sedang berjalan di antaranya adalah:

1. Belum adanya sistem informasi geografis atau Geography Information Sistem (GIS) yang mampu mengolah data lokasi daerah yang menerima daging Qurban di wilayah Kota Padang dengan cepat, akurat dan dapat diakses oleh pihak-pihak terkait, dimana saja dan kapan saja tanpa mengenal jarak dan waktu, sehingga akan lebih efisien baik dari segi waktu maupun biaya jika dibandingkan dengan melakukan survei lapangan secara lansung ke masing-masing lokasi.

2. Belum adanya ketersedian informasi lokasi daerah layak yang menerima daging Qurban di wilayah Kota Padang dalam memberikan informasi kepada instansi maupun pihak terkait secara spasial dengan begitu informasi yang di dapat akan lebih spesifik. 
3. Belum terintegrasinya penyimpanan data ke dalam basis data atau database yang mampu menampung data lokasi daerah yang layak menerima daging Quban di Wilayah Kota Padang. Selama ini penyimpanan data hanya berupa arsip-arsip yang mengakibatkan data tersebut mudah hilang, rusak dll.

Pada umumnya, untuk memetakan suatu lokasi penyebaran daging Qurban dilakukan survei secara lansung ke masing-masing lokasi. Hal ini sangat tidak efisien baik dari segi waktu maupun dari segi biaya serta informasi yang diperoleh terkadang tidak akurat dan hanya diperuntukan hanya pihak-pihak tertentu saja, sehingga masyarakat tidak dapat memperoleh informasi tersebut.

Dari permasalahan yang ada tersebut, maka diperlukan suatu aplikasi yang mampu mengelola data lokasi penyebaran daging Qurban di wilayah Kota Padang yang lebih efektive dan efisien, serta mampu memberikan suatu informasi baik kepada instansi terkait maupun kepada masyarakat. Perancangan sistem terinci bertujuan untuk memberi gambaran dan rancang bangun yang jelas kepada pemakai. Perancangan sistem terinci mencakup gambaran desain output desain input, desain database, dan desain file, serta desain relasi antar file.

Tahap implementasi merupakan tahap terakhir dalam pengembangan sistem, yaitu meletakkan sistem supaya siap dioperasikan. Sistem Informasi yang telah dibangun dan telah dilakukan pengetesan dari modul yang dirangkai. Sistem ini telah dianalis is dan didesain secara rinci dan didukung dengan memakai aplikasi pemrograman PHP, implementasinya berguna untuk memudahkan penerapan sistem yang telah disiapkan, agar pengentrian data sampai penyajian informasi sesuai dengan prosedur yang telah direncanakan.

Implementasi antar muka menggambarkan tampilan dari sistem yang dibangun. Berikut ini adalah implementasi antar muka dari sistem informasi geografis lokasi yang layak menerima daging Qurban di wilayah Kota Padang:

\subsection{Menu Input}

Program yang dirancang merupakan suatu programyang saling berkaitan antara satu menu dengan menu lainnya, maka user harus melakukan tahap demi tahap atau langkah-langkah yang sudah dirancang. Maka tahap pertama yang harus dilakukan oleh user adalah menginputkan data, berikut ini akan dijelaskan bentuk dari input data tersebut secara lebih rinci.

\section{Form Entry Data Masjid}

Halaman entry data Masjid ini merupakan halaman yang digunakan admin induk untuk menginputkan data-data Masjid yang berada di Kota Padang. Tampilan halaman entry data Masjid dapat dilihat pada Gambar 3.

\section{Q (2)}

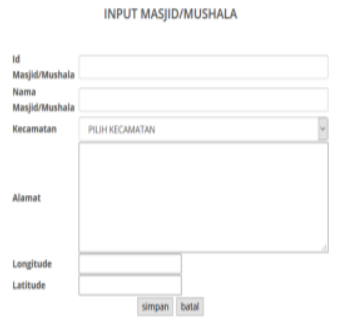

Gambar 3. Tampilan Form Entry Masjid

\section{Form Entry Pembagian}

Pada menu ini digunakan untuk memanipulasi data Qurban pada database. Penjelasannya dapat dilihat pada Gambar 4.

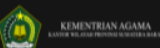

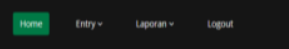

PEMBAGIAN

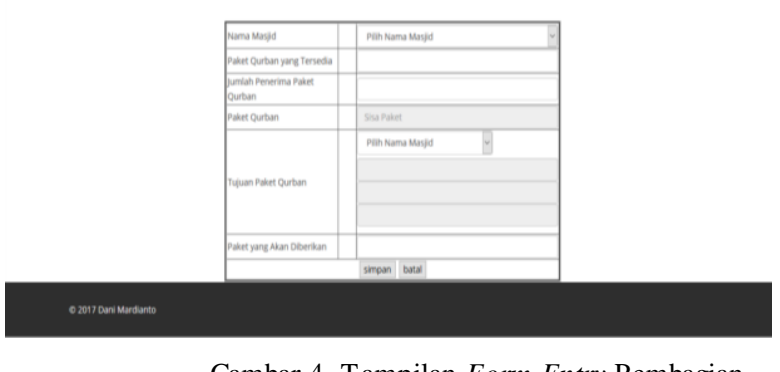

Gambar 4. Tampilan Form Entry Pembagian

\section{Form Entry Galeri}

Halaman entry galeri berfungsi sebagai penyampaian informasi berdas arkan gambar yang di input oleh admin. Tampilan halaman entry galeri dapat dilihat pada Gambar 5.

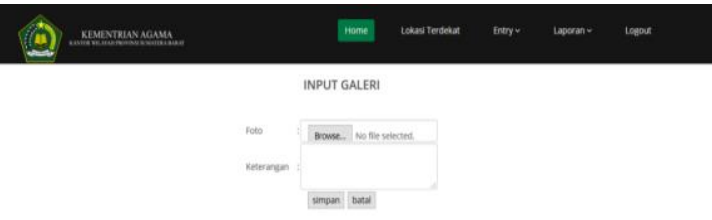

Gambar 5. Tampilan Form Entry Galeri

\subsection{Output}

\section{Lokasi terdekat}

Pada halaman lokasi distribusi daging Qurban dirancang agar user dapat melihat seluruh sebaran daging Qurban dalam bentuk peta dan informasi mengenai data-data yang berkaitan dengan distribusi daging Qurban 
tampilan halaman lokasi terdekat dapat dilihat pada Gambar 6.

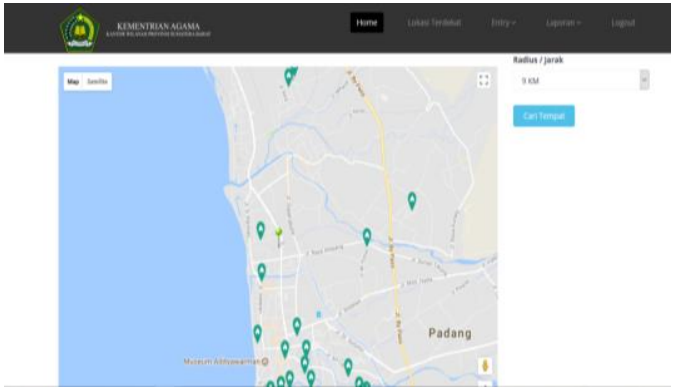

Gambar 6. Tampilan Terdekat

\section{Rute Perjalanan}

Menampilkan informasi rute perjalanan distribusi daging Qurban dengan menginputkan lokasi awal dan lokasi Masjid yang ditampilkan berbentuk garis berwarna biru serta terdapat jarak tempuh dan durasi atau waktu tempuh. Tampilannya dapat dilihat pada Gambar 7.

\section{(1) .}

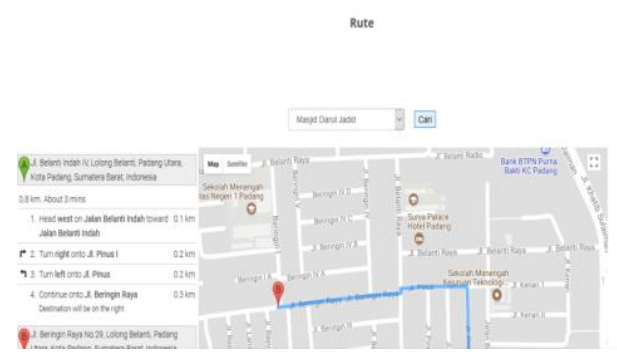

Gambar 7. Tampilan Rute Perjalanan

\section{Laporan Masjid}

Menu ini digunakan untuk mengetahui informasi mengenai data yang berkaitan tentang Masjid. Tampilannya dapat dilihat pada Gambar 8 .

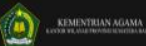

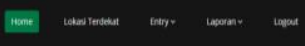

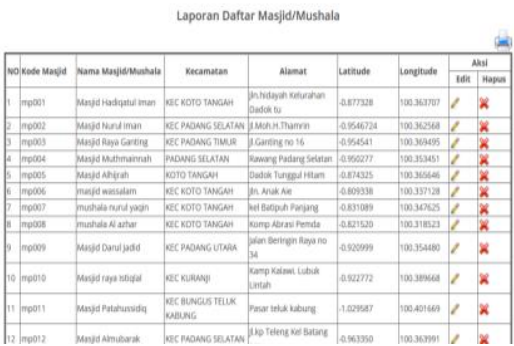

Gambar 8. Tampilan Laporan Masjid

\section{Laporan Pembagian}

Menu ini digunakan untuk mengetahui informasi data Qurban di wilayah Kota Padang. Tampilannya dapat dilihat pada Gambar 9.

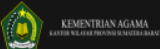

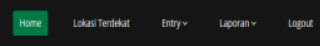

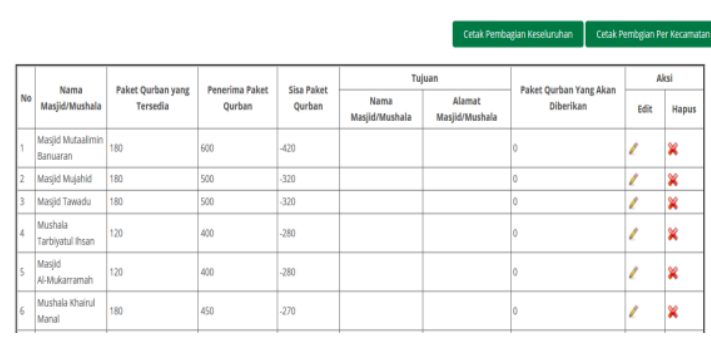

Gambar 9. Tampilan Laporan Pembagian

\section{Cetak Laporan}

Halaman cetak laporan Qurban berfungsi sebagai laporan cetak yang akan di tanda tangani oleh pihak yang berwenang. Tampilannya dapat dilihat pada Gambar 10.

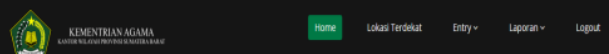

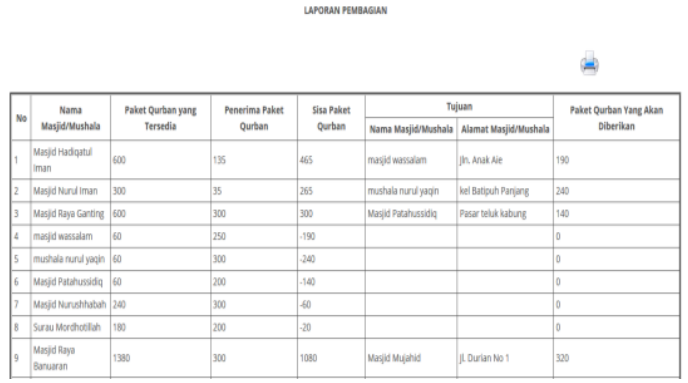

Gambar 10. Tampilan Cetak

\section{Kesimpulan}

\subsection{Simpulan}

Berdasarkan uraian yang dikemukakan pada bab-bab sebelumnya dapat disimpulkan dari penelitian yang dilakukan diharapkan bermanfaat bagi pembaca pada umumnya dan bagi pihak yang bersangkutan, adapun kesimpulannya yang dapat dikemukakan antara lain :

1. Sistem informasi geografis lokasi daerah yang layak menerima daging Qurban di wilayah Kota Padang memberikan kemudahan bagi Pengurus Masjid maupun Panitia Qurban dalam memberikan informasi lokasi mana saja yang jumlah Qurbannya masih minim.

2. Memberikan kemudahan bagi Panitia Qurban atau Pengurus Masjid dalam mencari lokasi yang layak menerima daging Qurban di wilayah Kota Padang, dikarenakan semua informasi mengenai daging Qurban telah tertera pada sistem.

3. Sistem informasi geografis lokasi daerah yang layak menerima daging Qurban di wilayah Kota Padang dapat menjadi jawaban terhadap permasalahan kurang meratanya pembagian daging Qurban di wilayah Kota Padang. 


\subsection{Saran}

Penelitian ini perlu ditingkatkan, seperti melakukan pengembangan sistem informasi geografis lokasi daerah yang layak menerima daging Qurban di wilayah Kota Padang dalam bentuk android yang bisa mengikuti perkembangan zaman pada saat ini. Penelitian ini juga dapat diperluas daerah penelitiannya bukan hanya di kota Padang akan tetapi daerahnya meliputi daerah Sumatera Barat. Begitu juga dengan informasi yang disajikan akan ditambah seperti penambahan informasi titik lokasi penjual hewan Qurban di daerah Sumatera Barat.

\section{Ucapan Terima Kasih}

Ucapan terima kasih kepada Yayasan Amal Bakti Mukmin yang telah memberikan dana dalam penulisan penelitian ini hingga selesai, sesuai dengan nomor kontrak 895.020/A.12/STMIK-I/2016. Dan pada akhir kata kami mengucapkan terima kasih kepada Ketua STMIK Indonesia Padang dan Ketua LPPM STMIK Indonesia Padang, yang telah mendorong dan terus memberikan semangat serta motivasi kepada Dosendosen agar terus maju dan berinovasi dalam melakukan penelitian.

\section{Daftar Rujukan}

[1] R. E. Ida Bagus Made Yogie Adnyana1, 2014, "Rancang Bangun Sistem Informasi Geografis Persebaran Lokasi Obyek Pariwisata Berbasis Web Dan Mobile Android (Studi Kasus Di Dinas Pariwisata Kabupaten Gianyar)," Teknol. Inf. dan Komun., vol. 5, pp. 16.

[2] M. S. Safuwan, M.Psi \& Subhani, S.Sos., 2013, "Pemberdayaan Kepribadian muslim Melalui Psikologi Qurban," Suwa, vol. XI, no. 1, pp. 77-82.

[3] S. Redjeki, M. Guntara, and P. Anggoro, 2014, "Perancangan Sistem Identifikasi Dan Pemetaan Potensi Kemiskinan Untuk Optimalisasi Program Kemiskinan Kemiskinan Merupakan Masalah Multidimensi dan Lintas Sektor Yang Dipengaruhi Oleh Berbagai Faktor Yang Saling Berkaitan, Antara Lain: Tingkat Pendapatan," J. Sist. Inf., vol. 6, no. 2, pp. 731-743.

[4] E. Prahasta, 2014, Sistem Informasi Geografis : KonsepKonsep Dasar (Perspektif Geodesi dan Geomatika), Bandung, Informatika Bandung.

[5] T. S. dan J. Fahana, 2010, "Pengembangan Aplikasi Untuk Menentukan Daerah Pencemaran Limbah Home Industry Berbasis Sistem Informasi Geografis," Informatika, vol. 4, no. 2, pp. 488-495.

[6] R.Noviati, 2017, "Praktik Kurban Online Dalam Perspektif Islam Tebar Hewan Kurban THK Di Dompet Dhuafa," Syarikah, vol. 3, no.1, pp.343-356.

[7] H. Wathan, 2017, "Pandangan Ulama Kota Medan Tentang Pelaksanaan Iddikhar Daging Qurban Di Rumah Zakat Medan -Sumatera Utara," Hum. Falah, vol. 4., no. 1, pp. 35-50.

[8] Y. Bustomi, M. A. Ramdhani, and R. Cahyana, 2012,"Rancang Bangun Sistem Informasi Geografis Sebaran Tempat Riset Teknologi Informasi Di Kota Garut," STT-Garut All Right Reserv., vol. 9, no. 20, pp. $1-7$.
[9] V. Motumona, U. Lestari, E. Fatkhiyah, and P. T. Informatika, 2016, "Sistem Informasi Geografis Lokasi Perguruan Tinggi Di Daerah Istimewa Yogyakarta Berbasis Mobile Android," Script, vol. 4, no. 1, pp.72-78.

[10] D. Novaliendry, 2013 “Aplikasi Game Geografi Berbasis Multimedia Interaktif (Studi Kasus Siswa Kelas IX SMPN Rao)," JTeknologi Dan Pendidik., vol. 6, no. 2, pp. 106118.

[11] B. Santosa, 2011,"Pemanfaatan Sistem Informasi Geografis Open Source Untuk Pelayanan Kesehatan Masyarakat Di Yogyakarta," Penelit. dan Pengemb. Pemerintah Provinsi DIY, vol. III, no. 4, pp. 1-8. 